\title{
Challenges of Milton Friedman's Contributions: A Perspective of Behavioral Economics
}

\author{
Di Zhu
}

\section{ABSTRACT}

This paper reviewed Milton Friedman's major contributions and critiqued his theories from a perspective of behavioral economics. Overall, behavioral economics can be a significant supplement to the traditional Friedman's theories to better predict economic events. More specifically, in terms of money supply, behavioral economics found that emotions can distort the assumption of the quantity theory of money and it may also affect economic output through its big role in decision making. As for the permanent income hypothesis, it can better explain the effect of income on consumption from the psychological aspect such as low confidence. His major point of a free market for economic and political freedom can be challenged by Nudge concept from behavioral economics. The government can help people to achieve their goals without damaging their autonomy. In addition, behavioral economics explores more and better reasons for the common phenomena of irrational behaviors against the traditional assumption that people are always rational.

Keywords: Behavioral Economics, Capitalism and Freedom, Irrational Behaviors, Milton Friedman, Money Supply, Permanent Income Hypothesis.
Submitted : August 12, 2021

Published : September 03, 2021

ISSN: 2507-1076

DOI: $10.24018 /$ ejbmr.2021.6.5.1053

\section{Di Zhu*}

Saint Mary's University of Minnesota, Minneapolis, MN, USA.

(e-mail: dxzhu17@ smumn.edu)

*Corresponding Author

\section{INTRODUCTION}

Milton Friedman is a representative of the Chicago school of economics and monetarists. $\mathrm{He}$ is well known for advocating free-market capitalism. In 1976, he was awarded the Nobel Prize in Economics for his achievements in the areas of income and consumption analysis, and monetary theory [1]. The behavioral economics challenges traditional assumption that in fact, people often fail to make ideal decisions due to heuristics and biases. This article examines five academic contributions of Friedman, which are the quantity theory of money, money supply, a theory of the consumption function, capitalism and freedom, and the methodology of positive economics, while it compares and contrasts his innovative work with behavioral economics approaching economic issues from the psychological perspective.

\section{MONETARISM-THE QUANTITY THEORY OF MONEY}

The monetarist school that studies whether money plays a role in economic operations is called the "Modern Quantity Theory of Money." The most prominent representative of this school is the famous American economist, Milton Friedman. In 1956, he published the article " Studies in the Quantity Theory of Money ", proposing the theory of pure money demand, that is, the quantity theory of money [2]. It attempts to re-express the quantity theory of money with a stable money demand function [3]. It does not consider the motives of people holding money, but only sets the utility of the currency like the Cambridge school, and then examines what factors determine how much money people want to hold.

The quantity theory of money holds that as long as the function of money demand is stable, changes in the money supply will cause changes in the price level [3]. Since money has the function as a medium of goods, it has high productivity, and this production capacity is the same as cash. The actual size of the balance holdings is directly related, thus determining the size of the capital stock, and the expansion of money demand will increase the total output [3].

The establishment of any theory contains certain assumptions, and the quantity theory of money is no exception. Here it does not intend to explore the premise of the theory itself, but to highlight the assumptions implied by the quantity theory of money, namely: the economy operates in a developed market economy; the capital market is perfect; the boundaries of property rights of the economic entities in the economic operation are clear and their behavior is independent. With this series of assumptions, the monetarists have come to the basic conclusions of the above-mentioned quantity theory of money. The price level will rise as the amount of money supply increases; the increase in the actual amount of money will lead to an increase in actual output. That is, increasing the money supply can promote economic development.

In short, Friedman argued that price level may vary with the change of money supply. The monetarist school represented by Friedman believed that the increase in the money supply will only cause the price level to rise without affecting the actual output in the long run, expressed in 
Friedman's "Studies in the Quantity Theory of Money." Nonetheless, in the short run, the elevated level of the money supply could result in an increase in employment and output and vice versa, as his paper stated.

The quantity theory of money implied the money demand may stay constant for a short period of time to observe the effect of money supply on output and employment. However, in reality, this is not the case because people are not always rational in terms of money demand. That is, the demand for money would change due to the change in emotion. From the perspective of psychology, a group of people whose have compulsive buying behavior (CBB) would overspend the money unexpectedly when they are in bad mood like anxiety and low self-esteem [4]. They have to rely heavily on the shopping spree to relieve their negative emotion [4]. This view from behavioral economics would challenge the assumption of the quantity theory of money.

\section{MONEY SUPPLY}

Friedman's other most well-known theory is that he proposed money supply as a factor in determining the value of production. Inflation is fundamentally derived from the idea of the money supply. In 1963, he and Anna Schwartz coauthored the book "A Monetary History of the United States, 1867-1960" to examine the link between money supply and economic activity in American history [5]. They came to the surprising conclusion that money supply has always been the only source of influence on economic activity [5].

The book focuses on the stock of money and studies the history of the currency development in the United States from 1867 to 1960 and its impact on a series of major historical events in the United States [6]. Through the careful depiction of the causal relationship between money supply changes and inflation levels, the author proves the far-reaching impact of monetary policy on a country's economic operations, especially the importance of money in a stable business cycle.

The book combines sophisticated historical statistics with a keen insight into economic analysis. The unique analysis of many perspectives in the book and the groundbreaking research conclusions, such as the author's analysis and interpretation of the Great Depression of 1929-1933, have transformed people's perceptions and deepened the understanding of financial markets by the global financial community. It changed the debate about the Great Depression. This book, familiar to all macroeconomists, examined in detail the changes in the U.S. money stock.

It claims only money supply can truly affect the economy in the book, while the behavioral economics would say this may not be true because of human beings' negative emotion affecting decision making [7], which would result in a declined return in the financial market. Some evidence suggested that the dismal return is a result of sentiment from the macro and micro levels [8]. The financial market, an important part of the economy, would be affected by the emotion other than money supply. Thus, with the help of behavioral economics, the emotional state level, as another variable, can be added to the research of money supply to better assess its effect on the economy.

\section{A THEORY OF THE CONSUMPTION FUNCTION}

Friedman's analysis of the consumption is also wellknown, that is, the permanent income hypothesis (PIH) he proposed in 1957 in "A Theory of the Consumption Function" [9]. This theory is regarded by some economists as his most important contribution to economic methodology. Its basic point of view is that consumer spending is largely determined not by his or her temporary income but by permanent income [9]. The permanent income refers to the long-term average income that consumers can expect. Permanent income can be roughly calculated from the weighted average of the observed annual income values. The closer to the current time, the greater the weight; otherwise, the smaller. According to this theory, the government's policy of increasing or decreasing taxes to affect aggregate demand is not effective, because people's increased income due to tax cuts will not be immediately used to increase consumption.

Friedman believed that consumer spending is determined by permanent income. That is to say, rational consumers, in order to maximize the utility, are not only based on the current temporary income but also based on the income level that can be expected in the long term, that is, the permanent income level largely influences consumption decisions. This theory divides people's income into temporary income and persistent income and considers consumption as a stable function of long-term income.

The tenets from behavioral economics are helpful in explaining how people psychologically respond to income fluctuation by changing their consumption behaviors. Transitory consumption that consumers tend to save much more than spend may be a result of consistent low confidence in the recovery of the economy after 2008 financial crisis [10]. Customers often face a prolonged period of declined income thereafter, so they adjust their behaviors accordingly, predicted by the PIH. The tenet of behavioral economics, from the micro-level, better illustrates why and how consumers' behaviors change of spending due to the income factor.

\section{CAPITALISM AND FREEDOM}

His book "Capitalism and Freedom" was published in 1962, which advocates the minimization of the role of the government to allow free markets to operate in order to maintain political and social freedom [11]. His political philosophy emphasizes the advantages of a free-market economy and opposes government intervention. His theory became one of the main economic bases of libertarianism, and it had a great influence on the economic policies of Reagan and many other countries that began in the 1980s.

The book focuses on Friedman's economic liberalism. It also introduced political freedom to further discuss its close relationship with economic freedom. Moreover, Friedman elaborated the inevitability of economic freedom from the development of human history. The book mainly clarifies two ideas: First, the ultimate goal of all activities in capitalist society is to achieve economic freedom, which is the basis for the realization of political freedom. Second, the intervention of national centralization on economic life is more harmful than the possible benefit. The scope of government functions 
should be limited and should be implemented as far as possible through market and price systems.

Traditional economics preferred the free market which works best in society, where the government needs to minimize its role in the market to ensure economic and political freedom. In contrast, behavioral economics introduced a concept called nudge [12]. Nudge is to exert a positive influence on individuals by the authorities [12]. It suggested the government may play a proactive and effective role in improving the society instead of occurring externality or cost to the society [12]. For instance, the retirement plans for savings directed properly by the local government can substantially help the workers to realize economic freedom without harming their political autonomy [12]. Thus, the findings of behavioral science are conducive for the government to find policies that truly help society to achieve social wellbeing and independence without much negative intervention on economic and political freedom.

\section{The Methodology of Positive Economics}

Friedman's paper "The Methodology of Positive Economics" in 1953 modeled his research methodology for decades to come and became one of the main frameworks of the Chicago school of economics [13]. He advocated that economics is a discipline that should be exempted from objective value judgment. In addition, whether an economic theory is useful or not, it should be based on how accurate it describes reality. Rather, it should be based on its effectiveness as a prediction of future economic events.

In this article, he argued that more seminal theory typically has more inaccurate assumptions that are seriously deviated from reality [14]. By contrast, behavioral economics often contended that many assumptions of theories of economics are not accurate and do not reflect reality [15]. For instance, the typical economic theory builds on the assumption that people are rational, whereas behavioral economics found this assumption is not as same as reality [16]. In reality, people are often confused and behaving irrationally [16].

\section{CONCLUSION}

This short review summarizes the significant contributions of Milton Friedman. First, the quantity theory of money implied that as long as the function of money demand is stable, money supply may cause changes in the price level. Nonetheless, a perspective from behavioral economics held that people are not always rational in terms of money demand. That is, the demand for money would change due to the change in emotion. Second, in his book, it said that only the money supply has a significant role in affecting the economic activities, whereas behavioral economics indicated that emotion from the micro and macro levels, as a vital factor, could affect economic performance such as financial market, through its big role in decision making.

Furthermore, as for the PIH, it argued that consumer spending is not only affected by temporary income but also determined by permanent income. However, behavioral economics does better in explaining psychological rationales behind income and the behavioral change of spending based on the variation of income. Moreover, his classical economics believed that government needs to minimize the role to guarantee economic and political freedom under a free market. Nevertheless, Nudge concept from behavioral economics contends that government can help society to grow and prosper without interfering with these freedoms. In addition, he claimed that many significant theories have unrealistic assumptions different from reality. In contrast, behavioral economics explained this difference from a psychological perspective such as predictable irrational behaviors different from the traditional assumption that people are always rational.

\section{REFERENCES}

[1] Skole, R. (1977). En-Nobeling Milton Friedman. Nation, 224(3), 68.

[2] Gurley, J. G. (1957). Studies in the quantity theory of money. The American Economic Review, 47(5), 732.

[3] Weintraub, S., \& Habibagahi, H. (1972). Money Supplies and PriceOutput Indeterminateness: The Friedman Puzzle. Journal of Economic Issues, 6(2-3), 1-13.

[4] Maccarrone-Eaglen, A., \& Schofield, P. (2017). Compulsive buying behavior: Re-evaluating its dimensions and screening. Journal of Consumer Behavior, 16(5), 463-473.

[5] Bordo, M. D., \& Rockoff, H. (2013). Not Just the Great Contraction: Friedman and Schwartz's A Monetary History of the United States 1867 to 1960. American Economic Review, 103(3), 61-65.

[6] Friedman, M., \& Schwartz, A. J. (2008). A monetary history of the United States, 1867-1960. Princeton University Press.

[7] Rick, S., \& Loewenstein, G. (2008). The role of emotion in economic behavior. Handbook of Emotions, 3, 138-158.

[8] Khuu, J., Durand, R. B., \& Smales, L. A. (2016). Melancholia and Japanese stock returns - 2003 to 2012. Pacific-Basin Finance Journal, 40, 424-437.

[9] DeJuan, J. P., \& Seater, J. J. (2006). A simple test of Friedman's permanent income hypothesis. Economica, 73(289), 27-46.

[10] Saisekar, A. (2012). Did consumers really change their consumption habits after the 2008 recession? A look into consumer expenditure using Milton Friedman's permanent income hypothesis. https://scholarship.claremont.edu/cmc_theses/508.

[11] Nolan, P. (2007). Capitalism and freedom: The contradictory character of globalization. Anthem Press.

[12] Kroncke, C. (2018). Nudging toward a stable retirement. Politics \& the Life Sciences, 37(1), 126-129.

[13] Mariyani-Squire, E. (2017). Critical reflections on a realist interpretation of Friedman's 'Methodology of Positive Economics'. Journal of Economic Methodology, 24(1), 69-89.

[14] Friedman, M. (1953). The methodology of positive economics. Retrieved from http://www.sfu.ca/ dandolfa/friedman-1966.pdf.

[15] Schwartz, A. (2015). Regulating for rationality. Stanford Law Review, 67(6), 1373-1410.

[16] Ariely, D. (2008). Predictably irrational: The hidden forces that shape our decisions. HarperCollins. 